\section{Research Square}

Preprints are preliminary reports that have not undergone peer review.

They should not be considered conclusive, used to inform clinical practice, or referenced by the media as validated information.

\title{
Genetic Testing of Leukodystrophies Unraveling Extensive Heterogeneity in a Large Cohort: The Role of Five Common Diseases and Report of 38 Novel Variants
}

\author{
Nejat Mahdieh \\ Iran University of medical sciences \\ Mahdieh Soveizi \\ Iran University of medical sciences \\ Alireza Tavasoli \\ Tehran University of Medical Sciences \\ Ali Rabbani \\ Tehran University of Medical Sciences \\ Mahmoudreza Ashrafi \\ Tehran University of Medical Sciences \\ Alfried Kohlschütter \\ University of medical center hamburg eppendorf \\ Bahareh Rabbani ( $\nabla$ baharehrabbani@yahoo.com ) \\ Tehran University of medical sciences
}

Research

Keywords: leukodystrophies, leukoencephalopathies, molecular genetic analysis, diagnosis

Posted Date: October 19th, 2020

DOI: https://doi.org/10.21203/rs.3.rs-93329/v1

License: (c) (i) This work is licensed under a Creative Commons Attribution 4.0 International License. Read Full License 


\section{Abstract}

Background: This study evaluates the genetic spectrum of leukodystrophies and leukoencephalopathies in Iran.

Methods: 152 children, aged from 1 day to 15 years, were genetically tested for leukodystrophies and leukoencephalopathies based on clinical and neuroradiological findings from 2016 to 2019. Patients with a suggestive specific leukodystrophy, e. g. metachromatic leukodystrophy, Canavan disease, Tay-Sachs disease were tested for mutations in single genes $(108 ; 71 \%)$ while patients with less suggestive findings were evaluated by NGS.

Results: 108 of 152(71\%) had MRI patterns and clinical findings suggestive of a known leukodystrophy. In total, 114(75\%) affected individuals had (likely) pathogenic variants which included 38 novel variants. 35 different types of leukodystrophies and genetic leukoencephalopathies were identified. The more common identified disorders included metachromatic leukodystrophy (19 of 152; 13\%), Canavan disease (12; 8\%), Tay-Sachs disease (11; 7\%), megalencephalic leukodystrophy with subcortical cysts (7; 5\%), X-linked adrenoleukodystrophy (8; 5\%), Pelizaeus-Merzbacher-like disease type 1 (8; $5 \%)$, Sandhoff disease $(6 ; 4 \%)$, Krabbe disease $(5 ; 3 \%)$, and vanishing white matter disease $(4 ; 3 \%)$. Whole exome sequencing (WES) revealed $26 \%$ leukodystrophies and genetic leukoencephalopathies. The total diagnosis rate was $75 \%$.

Conclusions: This unique study presents a national genetic data of leukodystrophies; it may provide clues to the genetic pool of neighboring countries. Patients with clinical and neuroradiological evidence of a genetic leukoencephalopathy should undergo a genetic analysis to reach a definitive diagnosis. This will allow a diagnosis at earlier stages of the disease, reduce the burden of uncertainty and costs, and will provide the basis for genetic counseling and family planning.

\section{Background}

Leukodystrophies and genetic leukoencephalopathies are a large heterogeneous group of genetic diseases affecting the white matter of the central nervous system. The single diseases are rare, but overall they affected 1 per 7663 live births, in a US American study[8]; the estimated prevalence of leukodystrophies is about 1-2/100 000 live births in Germany[4]. Most of these diseases are associated with severe progressive functional losses of motor and cognitive abilities, helplessness and early death. Their causes are either related to primary defects of myelin synthesis and myelin stability, but myelin damage may also be secondary to disturbances outside this structure[10]. Some mitochondrial and lysosomal storage disorders, organic acidemias, other inborn errors of metabolism and vascular disorders are also categorized under genetic leukoencephalopathies[4].

Leukodystrophies are clinically and genetically heterogeneous disorders; their diagnosis is challenging and nearly half of the patients will remain undiagnosed[1], putting a high economical and psychological burden on the society and the affected families. Many known genes have been recognized to cause these diseases, though there are many with unknown genetic etiology. Advances in gene sequencing procedures and whole exome sequencing (WES) unravel the genetic causes of leukodystrophies[6]. Genetic testing confirms the diagnosis and may offer a chance for disease-specific palliative treatment or experimental therapies of some diseases (e. g. metachromatic leukodystrophy, Alexander disease, and Krabbe disease). In addition, molecular genetic analysis would help for family screening and reproductive decisions. Most of the pediatric disorders follow an autosomal recessive pattern of inheritance and come from consanguineous marriages which are prevalent in Iran and the Middle East. Despite advances in molecular technologies and the high frequency of genetic diseases in Iran as the crossroads of the Middle East, there is no comprehensive study on genetics of pediatric white matter disorders in this region of the world. The genetic composition of different parts of Iran could be representative of the respective neighbors.

Here, we have evaluated the genetic spectrum of subjects clinically diagnosed with leukodystrophies referred to a tertiary pediatric center in Iran. The purpose of the study was to determine the common types of leukodystrophies and genetic leukoencephalopathies, neurological findings in the patients, and ethnical distribution of the disease.

\section{Methods}

\section{Patients}

Clinically diagnosed patients with white matter deterioration were enrolled in the study from different ethnicity of Iran between 2016 and 2019 . Clinical characteristics of leukodystrophies and leukoencephalopathies were approved by pediatric neurologists. Demographic data, medical and family history, physical evaluations, neurological examinations, magnetic resonance imaging (MRI), and laboratory testing of each patient were recorded for each patient. The study was approved by the ethical committee of Children's Hospital, Tehran University of Medical Sciences. Informed consent was obtained for genetic testing.

\section{Study Strategy}

\section{Single gene analysis based on clinical diagnosis}

Patients with a strongly suspected cause of their leukodystrophy were genetically analyzed for the respective relevant gene. These studies included the genes of metachromatic leukodystrophy (MLD), Canavan disease (CD), X-linked adrenoleukodystrophy (X-ALD), Alexander disease (AxD), Tay-Sachs disease, Sandhoff disease, Krabbe disease (KD), megalencephalic leukodystrophy with subcortical cysts (MLC), Sialic acid storage disease, Pelizaeus-Merzbacher disease (PMD), and Pelizaeus-Merzbacher-like disease type 1 (PMLD1).

DNA was extracted and amplified by using specific designed primers for coding regions (exons and exon-intron boundaries). The selected genes associated with leukodystrophy were classified to inherited autosomal recessive diseases: ARSA(NM_000487. 5), GALC(NM_000153. 3), MLC1(NM_015166. 3), 
BTD(NM_000060. 4), GFAP(NM_002055. 4), GJC2(NM_020435. 3), HEXB(NM_000521. 3), HEXA(NM_000520. 5), ASPA(NM_000049. 2) and

SLC17A5(NM_012434. 5), FAM126A(NM_032581. 3), and X-linked recessive ABCD1(NM_000033. 3), and PLP1(NM_001128834. 2), respectively. Direct

sequencing was performed by BigDye termination method ABI 3500 (Applied BioSystems, US).

\section{Next generation sequencing: gene-panel and whole exome sequencing (WES)}

Those patients with indefinite clinical diagnosis or overlapping symptoms and neurological findings underwent panel gene analysis to detect the genetic cause. Panel based gene analysis was performed for cases for 59 genes involving in leukodystrophy, leukoencephalopathy and vanishing matter white disease (Supplementary table 1). The coding regions and exon-intron boundaries of the genes were enriched using NimbleGen kit (NimbleGen, Roche, Basel, Switzerland). Sequencing analysis was performed by Illumina, Hiseq2000 (Illumina, San Diego, California, USA). Reads were aligned using Burrows-Wheeler Aligner (BWA) on reference genome (hg19) and annotated by SAMTools. Based on, 1000Genome and dbSNP database variant were selected for analysis. Coverage of target region with at least depth of $30 \mathrm{X}$ was $99.78 \%$. In addition, whole exome sequencing (WES) was performed with an average coverage depth of $\approx 100 X$. Sanger sequencing was done for the candidate variants in the affected families.

\section{Variant categories}

The sequence data were compared with public databases and filtered to find out the candidate variants according to published pipelines[10]. The candidate variants were categorized as the previously reported pathogenic variants and novel variants. ACMG guideline criteria were used to interpret novel variants and classify them[5].

\section{In silico analyses}

\section{Pathogenic effect}

According to HGVS (http://varnomen. hgvs. org/), novel variants were named as missense, nonsense, splice site, intronic, regulatory and indel. The following software tools were applied to predict the pathogenic effects of novel variants: polymorphism phenotyping (PolyPhen-2v2. 1)[4], combined annotation dependent depletion (CADD)[D1] and MutationTaster[4].

\section{Protein interaction}

STRING as a database for protein-protein interactions was used to figure out the interactions among proteins and co-expression of the studied proteins in human and other vertebrates. The studied proteins were investigated the co-expression in Homo sapiens to determine the function of proteins in cellular machinery by ProteomeHD[D1].

\section{Results}

\section{Patients' demographic data and clinical diagnoses}

A total of 152 patients, including 94 (62\%) males and 58 females, aged from 1 day to 15 year old, has been clinically diagnosed with leukodystrophy or genetic leukoencephalopathy. The distribution of the more common referred diseases among the patients was as follows: 25 patients clinically diagnosed with MLD, 13 CD, 10 PMLD, 6 PMD, 2 PMD or PMLD, 12 Tay-Sachs disease, 10 X-ALD, 8 Sandhoff disease, 8 MLC, 3 AxD, 3 KD, 4 hypomyelination and congenital cataract (HCC), 1 Sialic disease, 1 RNAse T2 deficient leukoencephalopathy, and 2 biotinidase deficiency .

Totally, 108 of 152 patient (71\%) had defined MRI patterns (not available) and were clinically diagnosed with a known leukodystrophy. Measurements of lysosomal enzymes in MLD, KD, Tay-Sachs disease, Sandhoff disease were performed for diagnosis. Urinary sulfatides (for e. g. MLD), plasma very long chain fatty acids (for e. g. X-ALD) were also tested to help the diagnosis. These patients were candidates for single gene analysis.

44 of 152 patients (29\%) had no definite MRI pattern and no definite biochemical or single gene test could be performed for them. They were candidates for panel gene analysis or WES.

\section{Demographic, clinical and genetic evaluation of patients confirmed genetically}

$114(75 \%)$ patients were confirmed based on genetic testing. Male consist of 73 of $114(64 \%)$ of patients. The mean age of onset was $5 \mathrm{yrs}$ and $1 \mathrm{~m} \pm 18 \mathrm{yrs}$ and $11 \mathrm{~m}$.

94 of $114(82.5 \%)$ cases were born in a consanguineous family. The ethnicity of these patients is compared in figure-1A. The ethnical distribution showed higher incidence in Fars 32\%; other ethnical distribution included 27\% in Turk, Arab 13\%, Lur 8\%, Kurd 7\%, Mazani $4 \%$, Gilak $3 \%$, and the rest Balooch, Afghan, Lak, and Turkeman(Figure-1A).

Based on age of onset of disease, 47 infantile ( $41 \%$ I), 17 late infantile ( $15 \%$ LI), 29 early juvenile (25\% EJ), 19 late juvenile (17\% LJ) and 2 adults (A) were available (supplementary table-2).

Thirty-five different leukodystrophies and genetic leukoencephalopathies were identified in this study (Table-1). The clinical characteristics of the most common genetically confirmed patients are summarized in table 1 and figure 1B. The main clinical manifestation was motor regression and neurological complaints including dystonia, hypotonia, developmental delay, ataxia, tremor, seizure, macrocephaly, nystagmus, cognition and learning impairment (Table-1 and Supplementary table-2). 


\section{Single gene analyses}

Sixteen patients had mutations in the ARSA gene (MLD), 8 in ABCD1 gene (X-ALD), 12 in ASPA gene (CD), 2 in GALC(GLB), 7 in MLC1 gene (MLC), 1 in GFAP gene, 1 in PLP1 gene (PMD), 8 in GJC2 gene (PMLD), 11 in HEXA, 5 in HEXB, and 1 in SCL 17A5 gene (Table 1). Totally, 74 out of 152 (49\%) patients were genetically diagnosed based on single gene analysis. The diagnostic rate was $69 \%$ (74 of 108), based on the clinical diagnosis (brain MRI) and single gene analysis.

\section{Next generation sequencing: gene-panel and WES}

Gene-panel and WES identified 40 of 152 (26\%) patients having leukodystrophies and leukoencephalopathies (Table-1, Supplementary Table-2). Four cases did not show any variants with multigene panel analysis of leukodystrophies.

38 of $152(25 \%)$ patients were not genetically confirmed based on genetic analysis. Some candidates of single gene analysis were not tested for panel based analysis because the parents were not satisfied for the test performance.

\section{Categorization of patients based on protein location}

\section{Lysosomal disorders}

Forty nine of 114 patients were diagnosed as lysosomal disorders (28 lysosomal LD and 21 lysosomal gLE). Forty-one patients genetically were confirmed for MLD, TSD, SD and KD (Table-1).

\section{Peroxisomal disorders}

Eleven patients were diagnosed as peroxisomal disorders which eight of them were X-ALD. One patient had peroxisomal single enzyme beta oxidation deficiency, and two patients had peroxisomal biogenesis disorders (Table-1).

\section{Errors of intermediary metabolism and other leukoencephalopathies}

Forty patients diagnosed as errors of intermediary metabolism, consisted of 12 CD, 8 PMLD and 7 MLC (Table 1). CD as the most common degenerative cerebral diseases, due to abnormal amino acid/organic acid metabolism, accounted for the second most common disease in our population. PMD and PMLD are disorders of myelin genes. 4 patients had vWM, 2 patients with hypomyelination-hypogonadotropic-hypogonadism-hypodontia, 1 hypomyalination and congenital contract, 1 PMD, 1 AD, 1 infantile neuroaxonal dystrophy/atypical neuroaconal dystrophy, 1 hypomyelination leukodystrophy 9 (HLD9), 1 Cockayene syndrome, and 1 biotinidase deficiency (Table-1 and supplementary table-2)

\section{Mitochondrial diseases}

Thirteen patients diagnosed with mitochondrial genetic leukoencephalopathies; Leigh syndrome and L-2-HGA accounted for 4 and 3 of them, respectively. Mutations in POLG gene encoding DNA polymerase subunit gamma-1 were responsible in two patients.

\section{Analysis of common genes and mutations}

The distribution of the most common diagnosed leukodystrophies accounted for $75 \%$ ( 86 of 114 patients) in our studied patients included 19 of 86 ( $22 \%$ ) MLD, 12 CD, 11 Tays-Sachs disease, 8 MLC, 8 X-ALD, 8 PMLD, 6 Sandhoff disease, 4 VWM (vanishing white matter leukoencephalopathy) and 3 L-2hydroxyglutaric aciduria disease (Figure-1B).

12 mutations observed in at least two unrelated patients which were as follow: 6 MLD patients had Gly311Ser and 3 patients had c. 465+1G>A in ARSA gene (data under publication), two X-ALD patients had c. 1415_1416delAG in ABDC1, six CD patients showed c. 634+1G>T in ASPA, three patients (two homozygotes and one compound heterozygote) had c. 237_238insA in ASPA, each c. 118G>C(p. Ala40Pro) and c. 733T>A(p. Cys245Ser) variant in GJC2 were observed in two PMLD patients which were novel variants, c. 1528C >T in HEXA observed in 4 of 11 TSD patients (2 were from Turkish, 1 from Fars, 1 from Mazani ethnicity), and c. 509G>A in HEXA was found in two Gilak patients, two of six Sandhoff disease patients had c. 833C>T and three (two homozygotes and one heterozygote) MLC patients had c. 449_455delTCCTGCT and two MLC patients had c. 177+1G>T.

\section{Novel variants}

Thirty-eight novel variants were identified in 40 patients (Table-2). Each of $A B C D 1$ and $G J C 2$ showed four novel variants. Following genes had each two novel variants: ASPA, FUCA, GALC, HEXA, L2HGDH and MLC1 (Table-2).

The variants were classified according to ACMG guideline; 12 variants met the criteria for being pathogenic, 18 and 11 variants were likely pathogenic and VUS, respectively.

One X-ALD patient had two variants as a haplotype because his mother was heterozygous for both (case5). These two variants considered as one haplotype, although they were classified as likely pathogenic variants.

\section{In silico analyses}


Protein interaction analysis predicted that the studied proteins had physical and functional relationships except proteins encoded by PLA2G6, RARS, SLC17A5, L2HGDH and MLC1 genes (Figure-2, supplementary table-3).

Functional association was predicted among different studied proteins. In co-expression prediction analysis (Data not shown), the following protein pairs such as POLG and SUCLA, in mitochondria were expressed together.

\section{Discussion}

Genetic diagnosis of childhood leukodystrophies is rapidly increasing throughout the past years in Iran and worldwide; approximately, 30 leukodystrophies and more that 60 disorders have been classified as genetic leukoencephalopathies[4]. This study provides a comprehensive spectrum of leukodystrophies and other genetic leukoencephalopathies in Iran as referred to a tertiary pediatric center. Totally, 35 types of leukodystrophies were determined in the studied population. Based on pattern of brain MRI and single gene analysis, approximately $69 \%$ of the referred patients were confirmed by direct Sanger sequencing. Clinical diagnosis reduced the number of genes to be evaluated. Panel based analysis also confirmed leukodystrophies in $26 \%$ of the cases. Our diagnostic rate of panel-based analysis was comparable to other studies[6]. Three patients were genetically undiagnosed with panel-based studies and WES/WGS is needed to define the causes. Consequently, we had $25 \%$ unsolved genetic cases and the diagnostic rate was $75 \%$ of leukodystrophies and genetic leukoencephalopathies in the study. Various novel variants identified, show that a high rate of allelic heterogeneity exists among our patients. A specific composition of population living in Iran complicates this picture; different ethnicities with specific cultural customs demand to run more specific investigations on each population.

MLD was the most common cause of leukodystrophies in our population. The next diseases were CD, Tays-Saches, PMLD, X-ALD and then MLC. MLC is the most common (6 of 23) among Turk patients while PMLD may be common among Arab population in our study. Moreover, ten common diseases of this study, compromise $70 \%$ of all recognized patients (80 of 114) (Table-1).

Clinically, we had unsolved cases due to variable phenotypic features or overlapping neurological manifestations which were candidates of gene-panel and/or WES analysis. Despite we had patients with no genetic diagnosis even though they had undergone panel-based analysis. This could be due to intronic variants, copy number variations, unknown gene defects, and multigenic effect. Therefore more genetic analysis should be performed for these cases.

Our understanding of in silico protein analysis and prediction analysis showed that interaction of proteins are beyond single cell type or physiological condition; proteins are highly specific and could interact without binding e. g. transcription factors in expression regulation. The functional association predicted the interaction between two proteins to a joint biological function[D1]. Five proteins did not show any association with other proteins in leukodystrophies and leukoencephalopathies in our study. It is surprising that these proteins were not associated in leukodystrophies pathways and showed no functional interaction. To name, PLA2G6, MLC1, L2HGDH, RARS, SLC17A5 showed no association. All these proteins have relationship with metabolism and function of cells but did not show interaction in prediction analysis. Therefore, for rare diseases genetic analysis, WES may unravel more genes relating to leukodystrophies in patients with unsolved genetics.

Lysosomal diseases had $43 \%$ incidence in our studied population which could be managed at earlier age of diagnosis. Individuals with known causal variants benefit from unexpected clinical presentations, prognosis, pallitative treatment and avoiding unnecessary treatments. Hematopoietic stem cell transplantation (HSCT) has been used for lysosomal storage diseases[5]. Some of our patients might potentially have benefitted from HSCT at early stages of the disease. However, patients' follow up for HSCT is out of the scope of this study.

Some have an ethnic-specific distribution, e. g. TSD in Ashkenazi Jewish population, GM1 gangliosidosis in Rudari isolate and MLD in Western Navajo Nation[1]. MLD patients were from western part of Iran (data under publication). Four of our TSD patients were from northern parts of Iran.

The peroxisomal disorders, as a heterogeneous group, occur due to a defect in function (e. g. X-ALD) and biogenesis (e. g. Zellweger spectrum) of peroxisomes. X-ALD is the most common peroxisomal disorder caused by mutation in the $A B C D 1$ gene co-expressed with HSD17B4 gene (Figure-2). Patients with X-ALD could benefit from HSCT[7] or hematopoietic stem-cell gene therapy[17].

$\mathrm{CD}$ is the second frequent disease in our study. It is the most common disease during infancy and has been observed mainly in Ashkenazi Jews while in our study patients were from various ethnicities. Various experimental therapies for Canavan patients are under investigation[3]. Patients with known genetic etiology may benefit from such experimental therapies.

PMLD is responsible for $8 \%$ of hypomyelinating leukodystrophy patients[10]. In this study $7 \%$ of the patients had the disease. In addition to GJC2, mutations in other genes such as a Myelin-associated glycoprotein (MAG) gene have been reported to cause PMLD[Pt 9]. GJC2 is co-expressed with PLP1 and interacts with products of FAM1256A, POLR3A and EIF2B5 genes (Figure-2). Our results highlighted that PMLD may have a higher frequency than PMD in our population especially in Arab and Fars ethnicities.

Additionally, our prediction analysis showed that MLC1 protein had no interaction or expression with other studied proteins. Six of them were from Turk ethnicity; it may be a common disorder and limit to specific ethnicity e. g. from Turkey.

$11 \%$ of patients diagnosed with mitochondrial genetic leukoencephalopathies; Leigh syndrome and L-2-HGA accounted for 4 and 3 of them, respectively. Leigh spectrum was due to SURF1. Also, it was due to NDUFS1, NDUFS7 and SDHAF1 genes. L2HGDH encoding mitochondrial L-2-hydroxyglutarate dehydrogenase may be common in our ethnicities. Its protein showed no interaction with other proteins of our study, instead it has interaction with other proteins. The mechanism of leukodystrophy is very complicated and there may be proteins involved in disease progress which show overlapping phenotype but have no or unknown interaction with each other. 
Ancestral or founder effect or a genetic signature within an ethnicity usually leads to a high frequency and homozygosity of a mutation in that cohort; in contrast, if a specific mutation is distributed uniformly among many ethnicities, it is known as a mutational hotspot. Haplotype analysis is used to define recognized that a mutation is a hotspot or a founder one. The studied mutations of ABCD1(c. 1415_1416delAG), ASPA(c. 634+1G>T and c. 237_238insA) and HEXA (c. $1528 \mathrm{C}>\mathrm{T}$ ) show a wide distribution around the world[2,1,4,6]; especially c. $634+1 \mathrm{G}>\mathrm{T}$ in ASPA gene has been reported from Turkey for the first time and we found it in patients from Fars, Afghani, Lur and Arab ethnicities[1]. These mutations are considered as hotspots i. e. they are mutated in many populations. Contrarily, mutations of $M L C 1$ (c. 177+1G>T and c. 449_455delTCCTGCT) may have ancestors in Turk population. Especially, the c. 449_455delTCCTGCT variant was observed in three families; it may be originated from a founder ancestor in Turk population and it previously has been reported from Turkey[3].

\section{Challenges and limitations}

We have not included all the affected patients in our registry, only the patients referred to our center for genetic testing were accounted in this study. In addition, Children's Hospital is a tertiary center in Tehran and some patients around the country may have not been registered and/or died previously before registration. Therefore, a multicenter registry is needed. The incidence of the disease in this part of the world may be different due to consanguineous marriages. Ethnical background had higher incidence in Fars and Turk; however, the population of these ethnicities is also high in Iran.

\section{Conclusion}

In conclusion, this study gains other studies in the distribution of genetics of leukodystrophies in Middle East. Genetic analysis provides diagnostic confirmation of the disease, and physicians are allowed for prognosis and management of patients and affected families. Genetic testing following counseling decreases further worry of the family about the diagnosis and further costs. The mortality rate in affected families is very high and it underscores the necessity of genetic testing in the country. Moreover, treatments for some diseases at early stages are successful before initiation of presymptomatic stage. Enzyme replacement, metabolic correction, cell-based therapies at the right time increases the patient's life span. This study provides information to help for future therapeutic planning's in the country.

\section{Declarations}

\section{Ethics approval and Patients' consent}

Ethical approval was supported by Growth and development research center, Tehran University of Medical Sciences ID number 98-02-80-43432. Informed consent was obtained from the patients.

\section{Consent for publication}

All contributing authors have read the manuscript and given their consent for the publication of this study.

\section{Availability of supporting data}

There are no additional unpublished data. MLD data is under publication.

\section{Competing interests}

None of authors declared any conflict of interest.

\section{Funding}

This work has no funding support and approved by Tehran University of Medical Sciences

\section{Author's contribution}

N. M. : Study design, data analysis, project administrator, writing and review editing

M. S. : Data extraction, data validation, data analysis, review editing

A. T. : Clinical evaluation

A. R. : Clinical evaluation

M. A : Clinical evaluation

A. $\mathrm{K}$ : Review editing

B. R. : Study design, Data validation, Data analysis, Writing and review editing

\section{Acknowledgement}


The study was supported by Growth and Development Research Center. Genetic testing was performed in genetic laboratory.

\section{References}

1. Bonkowsky JL, Nelson C, Kingston JL, Filloux FM, Mundorff MB, Srivastava R. The burden of inherited leukodystrophies in children. Neurology 2010; 75 : 718-725.

2. Heim P, Claussen M, Hoffmann B, Conzelmann E, Gartner J, Harzer K, et al. Leukodystrophy incidence in Germany. Am J Med Genet 1997; 71 : 475-478.

3. Kohlschutter A, Eichler F. Childhood leukodystrophies: a clinical perspective. Expert Rev Neurother 2011; 11: 1485-1496.

4. Vanderver A, Prust M, Tonduti D, Mochel F, Hussey HM, Helman G, et al. Case definition and classification of leukodystrophies and leukoencephalopathies. Mol Genet Metab 2015; 114: 494-500.

5. van der Knaap MS, Breiter SN, Naidu S, Hart AA, Valk J. Defining and categorizing leukoencephalopathies of unknown origin: MR imaging approach. Radiology 1999; 213: 121-133.

6. Vanderver A, Simons C, Helman G, Crawford J, Wolf NI, Bernard G, et al. Whole exome sequencing in patients with white matter abnormalities. Ann Neurol 2016; 79: 1031-1037.

7. Rabbani B, Mahdieh N, Hosomichi K, Nakaoka H, Inoue I. Next-generation sequencing: impact of exome sequencing in characterizing Mendelian disorders. J Hum Genet 2012; 57: 621-632.

8. Richards S, Aziz N, Bale S, Bick D, Das S, Gastier-Foster J, et al. Standards and guidelines for the interpretation of sequence variants: a joint consensus recommendation of the American College of Medical Genetics and Genomics and the Association for Molecular Pathology. Genet Med 2015; 17 : 405-424.

9. Adzhubei IA, Schmidt S, Peshkin L, Ramensky VE, Gerasimova A, Bork P, et al. A method and server for predicting damaging missense mutations. Nat Methods 2010; 7: 248-249.

10. Rentzsch P, Witten D, Cooper GM, Shendure J, Kircher M. CADD: predicting the deleteriousness of variants throughout the human genome. Nucleic Acids Res 2019; 47: D886-D894.

11. Schwarz JM, Cooper DN, Schuelke M, Seelow D. MutationTaster2: mutation prediction for the deep-sequencing age. Nat Methods 2014; 11: $361-362$.

12. Szklarczyk D, Gable AL, Lyon D, Junge A, Wyder S, Huerta-Cepas J, et al. STRING v11: protein-protein association networks with increased coverage, supporting functional discovery in genome-wide experimental datasets. Nucleic Acids Res 2019; 47: D607-D613.

13. Boelens JJ, van Hasselt PM. Neurodevelopmental Outcome after Hematopoietic Cell Transplantation in Inborn Errors of Metabolism: Current Considerations and Future Perspectives. Neuropediatrics 2016; 47: 285-292.

14. Platt FM, d'Azzo A, Davidson BL, Neufeld EF, Tifft CJ. Lysosomal storage diseases. Nat Rev Dis Primers 2018; 4: 27.

15. Miller WP, Rothman SM, Nascene D, Kivisto T, DeFor TE, Ziegler RS, et al. Outcomes after allogeneic hematopoietic cell transplantation for childhood cerebral adrenoleukodystrophy: the largest single-institution cohort report. Blood 2011; 118: 1971-1978.

16. Eichler F, Duncan C, Musolino PL, Orchard PJ, De Oliveira S, Thrasher AJ, et al. Hematopoietic Stem-Cell Gene Therapy for Cerebral Adrenoleukodystrophy. N Engl J Med 2017; 377: 1630-1638.

17. Pleasure D, Guo F, Chechneva O, Bannerman P, McDonough J, Burns T, et al. Pathophysiology and Treatment of Canavan Disease. Neurochem Res 2020; 45: 561-565.

18. Henneke M, Combes P, Diekmann S, Bertini E, Brockmann K, Burlina AP, et al. GJA12 mutations are a rare cause of Pelizaeus-Merzbacher-like disease. Neurology 2008; 70: 748-754.

19. Lossos A, Elazar N, Lerer I, Schueler-Furman O, Fellig Y, Glick B, et al. Myelin-associated glycoprotein gene mutation causes Pelizaeus-Merzbacher diseaselike disorder. Brain 2015; 138: 2521-2536.

20. Kemp S, Ligtenberg MJ, van Geel BM, Barth PG, Wolterman RA, Schoute F, et al. Identification of a two base pair deletion in five unrelated families with adrenoleukodystrophy: a possible hot spot for mutations. Biochem Biophys Res Commun 1994; 202: 647-653.

21. Rady PL, Penzien JM, Vargas T, Tyring SK, Matalon R. Novel splice site mutation of aspartoacylase gene in a Turkish patient with Canavan disease. Eur J Paediatr Neurol 2000; 4: 27-30.

22. Elpeleg ON, Shaag A. The spectrum of mutations of the aspartoacylase gene in Canavan disease in non-Jewish patients. J Inherit Metab Dis $1999 ; 22$ : 531-534.

23. Kaya N, Al-Owain M, Abudheim N, Al-Zahrani J, Colak D, Al-Sayed M, et al. GM2 gangliosidosis in Saudi Arabia: multiple mutations and considerations for future carrier screening. Am J Med Genet A 2011; 155A: 1281-1284.

24. Leegwater PA, Boor PK, Yuan BQ, van der Steen J, Visser A, Konst AA, et al. Identification of novel mutations in MLC1 responsible for megalencephalic leukoencephalopathy with subcortical cysts. Hum Genet 2002; 110: 279-283.

\section{Tables}


Table 1:

The distribution of the leukodystrophies and genetic leukoencephalopathies based on single gene analysis and WES/panel based gene sequencing in 114 positive patients in the studied population.

\begin{tabular}{|c|c|c|c|c|c|c|c|c|c|}
\hline \multirow[t]{2}{*}{ No. } & \multirow[t]{2}{*}{ Name of Disease } & \multirow{2}{*}{$\begin{array}{l}\text { Alternative } \\
\text { designation, } \\
\text { abbreviation }\end{array}$} & \multirow[t]{2}{*}{ MIM \# } & \multirow[t]{2}{*}{ Gene } & \multirow{2}{*}{$\begin{array}{l}\text { Location of } \\
\text { protein }\end{array}$} & \multirow{2}{*}{$\begin{array}{l}\text { No of } \\
\text { families } \\
(\%)\end{array}$} & \multicolumn{2}{|c|}{ Genetic testing } & \multirow[t]{2}{*}{ Phenotypes } \\
\hline & & & & & & & $\begin{array}{l}\text { Single } \\
\text { gene }\end{array}$ & WES & \\
\hline & \multicolumn{9}{|l|}{ Leukodystrophies } \\
\hline 1 & $\begin{array}{l}\text { Metachromatic } \\
\text { leukodystrophy }\end{array}$ & MLD & 250100 & ARSA & ER, Lysosome & $\begin{array}{l}19(16 . \\
7)\end{array}$ & 16 & 3 & $\begin{array}{l}\text { AG:2, MR:15, DD:2, } \\
\mathrm{Cl}: 1, \text { speech problem: } 6\end{array}$ \\
\hline 2 & Krabbe Disease & $\mathrm{KD}$ & 245200 & GALC & Lysosome & $5(4.4)$ & 3 & 2 & $\begin{array}{l}\text { Hypotonia:1, speech } \\
\text { problem: } 2 \text {, Spasticity: } \\
\text { 2, AG: } 2 \text {, Seizure: } 2 \text {, MR: } \\
5, \text { DD:2 }\end{array}$ \\
\hline 3 & Fucosidosis & & 230000 & FUCA1 & Lysosome & $2(1.8)$ & 0 & 2 & $\begin{array}{l}\text { Hypotonia:1, Dental } \\
\text { germination:1, skin } \\
\text { lesions:1, AG:1, DD: } 2\end{array}$ \\
\hline 4 & Salla Disease & SD & 604369 & SLC17A5 & $\begin{array}{l}\text { Lysosomal and } \\
\text { cell membrane }\end{array}$ & $1(0.9)$ & 1 & 0 & $\begin{array}{l}\text { speech problem, } \\
\text { Seizure, DD, MD }\end{array}$ \\
\hline 5 & $\begin{array}{l}\text { Multiple sulfatase } \\
\text { deficiency }\end{array}$ & MSD & 272200 & SUMF1 & ER & $1(0.9)$ & 0 & 1 & $\begin{array}{l}\text { dried skin, spasticity, } \\
\text { incapable to walk and } \\
\text { talk, } R \text {, mental } \\
\text { retardation, coarse } \\
\text { facial feature }\end{array}$ \\
\hline 6 & RNAse T2 deficiency & & 612944 & RNASET2 & $\begin{array}{l}\text { ER, Lysosome, } \\
\text { Extracellular }\end{array}$ & $1(0.9)$ & 0 & 1 & Hypotonia, DD \\
\hline 7 & $\begin{array}{l}\text { X-linked } \\
\text { adrenoleukodystrophy }\end{array}$ & $X-A L D$ & 300100 & ABCD1 & $\begin{array}{l}\text { Membrane of ER, } \\
\text { Mitochondrion, } \\
\text { peroxisome and } \\
\text { lysosome }\end{array}$ & $8(7)$ & 8 & 0 & $\begin{array}{l}\text { Hypotonia: 2, Vision } \\
\text { problem: 1, Feeding } \\
\text { problem: 2, AG: 3, } \\
\text { Seizure: 2, MR: 2, LD:1, } \\
\text { Cl: } 4\end{array}$ \\
\hline 8 & $\begin{array}{l}\text { Rhizomelic } \\
\text { chondrodysplasia } \\
\text { punctata }\end{array}$ & RCDP & 601757 & PEX7 & Peroxisome & $1(0.9)$ & 0 & 1 & $\begin{array}{l}\text { coarse facial feature, } \\
\text { cataract, digestive } \\
\text { problem, DD, MR }\end{array}$ \\
\hline 9 & Zellweger Spectrum & ZS & 614883 & PEX13 & $\begin{array}{l}\text { Peroxisome } \\
\text { membrane }\end{array}$ & $1(0.9)$ & 0 & 1 & $\begin{array}{l}\text { Hypotonia, Seizure, } \\
\text { MR, feeding problem }\end{array}$ \\
\hline 10 & $\begin{array}{l}\text { D-bifunctional protein } \\
\text { deficiency }\end{array}$ & DBPD & 601860 & HSD17B4 & Peroxisome & $1(0.9)$ & 0 & 1 & $\begin{array}{l}\text { swallowing problem, } \\
\text { walking difficulty, } \\
\text { speech problem, MR }\end{array}$ \\
\hline 11 & Canavan Disease & $\mathrm{CD}$ & 271900 & ASPA & $\begin{array}{l}\text { Nucleus, } \\
\text { Cytoplasm }\end{array}$ & $\begin{array}{l}12(10 . \\
5)\end{array}$ & 12 & 0 & $\begin{array}{l}\text { Hypotonia:8, } \\
\text { Nystagmus and eye } \\
\text { problem:5, } \\
\text { Macrocephaly:9, } \\
\text { Spasticity:3, Irritable:6, } \\
\text { Seizure:3, R: 9, DD:7 }\end{array}$ \\
\hline 12 & $\begin{array}{l}\text { Pelizaeus-Merzbacher- } \\
\text { like disease type }\end{array}$ & PMLD & 260600 & GJC2 & $\begin{array}{l}\text { Cell membrane, } \\
\text { gap junction }\end{array}$ & $8(7)$ & 6 & 2 & $\begin{array}{l}\text { Hypotonia: } \\
\text { 6,Nystagmus: 8, } \\
\text { Ataxia: 4, Speech } \\
\text { problem:6, DD:6 }\end{array}$ \\
\hline 13 & $\begin{array}{l}\text { Megalencephalic } \\
\text { leukoencephalopathy } \\
\text { with subcortical cysts }\end{array}$ & MLC & 604004 & MLC1 & $\begin{array}{l}\text { ER and cell } \\
\text { membrane }\end{array}$ & $7(6.1)$ & 7 & 0 & $\begin{array}{l}\text { Macrocephaly:7, } \\
\text { Dystonia: 2, AG: } 4, \\
\text { Seizure: 2, MD:2, MR:5 }\end{array}$ \\
\hline \multirow[t]{3}{*}{14} & \multirow{3}{*}{$\begin{array}{l}\text { Vanishing white matter } \\
\text { disease }\end{array}$} & \multirow[t]{3}{*}{ vWM } & 606273 & EIF2B3 & Cytosol & $1(0.9)$ & 0 & 1 & \multirow{3}{*}{$\begin{array}{l}\text { MR:4, Hypotonia: } \\
\text { 3,Tremor: 2, AG: 2, } \\
\text { Seizure: 2, speech } \\
\text { problem } 1\end{array}$} \\
\hline & & & 603945 & EIF2B5 & Cytosol, nucleus & $2(1.8)$ & 0 & 2 & \\
\hline & & & 606687 & EIF2B4 & Cytosol & $1(0.9)$ & 0 & 1 & \\
\hline \multirow[t]{2}{*}{15} & \multirow{2}{*}{$\begin{array}{l}\text { Hypomyelination- } \\
\text { hypogonadotropic } \\
\text { hypogonadism- } \\
\text { hypodontia }\end{array}$} & \multirow[t]{2}{*}{$4 \mathrm{H}$} & 614366, & POLR3A & Nucleus & $1(0.9)$ & 0 & 1 & \multirow{2}{*}{$\begin{array}{l}\text { Hypotonia: 2, speech } \\
\text { problem: 2, Tremor:1, } \\
\text { ataxia:2, AG: 2, } \\
\text { Seizure:2, MR:1, DD:1, } \\
\text { nystagmus:1 }\end{array}$} \\
\hline & & & 614381 & POLR3B & Nucleus & $1(0.9)$ & 0 & 1 & \\
\hline 16 & $\begin{array}{l}\text { hypomyelination and } \\
\text { congenital cataract }\end{array}$ & $\mathrm{HCC}$ & 610532 & FAM126A & Cytosol & $1(0.9)$ & 0 & 1 & congenital cataract \\
\hline 17 & $\begin{array}{l}\text { Pelizaeus-Merzbacher } \\
\text { disease }\end{array}$ & PMD & 312080 & PLP1 & $\begin{array}{l}\text { Cell (myelin) } \\
\text { membrane }\end{array}$ & $1(0.9)$ & 1 & 0 & $\begin{array}{l}\text { MR, Hypotonia, } \\
\text { nystagmus }\end{array}$ \\
\hline 18 & Alexander disease & $A \times D$ & 203450 & GFAP & Cytoplasm & $1(0.9)$ & 1 & 0 & $\begin{array}{l}\text { Seizure, R, DD, } \\
\text { hypotonia }\end{array}$ \\
\hline
\end{tabular}




\begin{tabular}{|c|c|c|c|c|c|c|c|c|c|}
\hline 19 & $\begin{array}{l}\text { infantile neuroaxonal } \\
\text { dystrophy/atypical } \\
\text { neuroaxonal dystrophy }\end{array}$ & INAD & 603604 & PLA2G6 & $\begin{array}{l}\text { Peripheral } \\
\text { membrane }\end{array}$ & $1(0.9)$ & 0 & 1 & $\begin{array}{l}\text { Hypotonia, bristling } \\
\text { head, Seizure }\end{array}$ \\
\hline \multirow[t]{2}{*}{20} & $\begin{array}{l}\text { Hypomyelinating } \\
\text { leukodystrophy-9 }\end{array}$ & HLD9 & 616140 & RARS & Cytosol & $1(0.9)$ & 0 & 1 & $\begin{array}{l}\text { Spasticity, hypotonia, } \\
\text { MD }\end{array}$ \\
\hline & \multicolumn{9}{|l|}{$\begin{array}{l}\text { Genetic } \\
\text { Leukoencephalopathies }\end{array}$} \\
\hline 21 & Tay-Sachs Disease & TSD & 272800 & HEXA & Lysosome & $\begin{array}{l}11(9 . \\
6)\end{array}$ & 11 & 0 & $\begin{array}{l}\text { Vision problem and } \\
\text { nystagmus:8, R:6, DD:4 }\end{array}$ \\
\hline 22 & Sandhoff disease & SHS & 606873 & HEXB & Lysosome & $6(5.3)$ & 5 & 1 & $\begin{array}{l}\text { Visual problem:2, } \\
\text { Seizure:1, R:4, DD:4 }\end{array}$ \\
\hline 23 & Gangliosidosis & GM1 & 230500 & GLB1 & Lysosome & $1(0.9)$ & 0 & 1 & \\
\hline \multirow[t]{2}{*}{24} & \multirow{2}{*}{$\begin{array}{l}\text { Neuronal Ceroid- } \\
\text { Lipofuscinoses }\end{array}$} & \multirow[t]{2}{*}{$\mathrm{NCL}$} & \multirow[t]{2}{*}{204300} & PPT1, & \multirow{2}{*}{$\begin{array}{l}\text { Extracellular, } \\
\text { Lysosome } \\
\text { ER membrane }\end{array}$} & $1(0.9)$ & 0 & 1 & \multirow{2}{*}{$\begin{array}{l}\text { Hypotonia:1, speech } \\
\text { problem:2, AG: 2, } \\
\text { Seizure:2, MR:2, DD:1 }\end{array}$} \\
\hline & & & & CLN6 & & $1(0.9)$ & 0 & 1 & \\
\hline 25 & $\begin{array}{l}\text { Mucopolysaccharidosis } \\
\text { type IIIB }\end{array}$ & MPS IIIB & 609701 & NAGLU & Lysosome & $1(0.9)$ & 0 & 1 & $\begin{array}{l}\text { coarse facial feature, } \\
\text { macrocephaly }\end{array}$ \\
\hline 26 & Cockayne Syndrome & CS & 609413 & ERCC6 & Nucleus & $1(0.9)$ & 0 & 1 & $\begin{array}{l}\text { Microcephaly, AG, } \\
\text { MR/R }\end{array}$ \\
\hline 27 & Biotinidase deficiency & BTD & 253260 & BTD & Extracellular & $1(0.9)$ & 1 & 0 & Seizure \\
\hline 28 & $\begin{array}{l}\text { L-2-hydroxyglutaric } \\
\text { aciduria }\end{array}$ & L-2-HGA & 236792 & L2HGDH & Mitochondrion & $3(2.6)$ & 2 & 1 & $\begin{array}{l}\text { Hypotonia:1, } \\
\text { Macrocephaly:1, } \\
\text { speech problem: 1, } \\
\text { tremor: 1, AG: 1, } \\
\text { Seizure: 1, DD: 3, LD:1, } \\
\text { Mental retardation:3 }\end{array}$ \\
\hline 29 & Glutaric acidemia IIC & GAllC & 231680 & ETFDH & $\begin{array}{l}\text { Mitochondrion } \\
\text { inner membrane }\end{array}$ & $1(0.9)$ & 0 & 1 & $\begin{array}{l}\text { Walking problem, } \\
\text { speech problem, } \\
\text { digestive problem, MR }\end{array}$ \\
\hline 30 & $\begin{array}{l}\text { Mitochondrial DNA } \\
\text { depletion syndrome } 5\end{array}$ & MDDS5 & 612073 & SUCLA2 & Mitochondrion & $1(0.9)$ & 0 & 1 & Dystonia, R, DD \\
\hline 31 & $\begin{array}{l}\text { Ataxia neuropathy } \\
\text { spectrum }\end{array}$ & ANS & 203700 & POLG & Mitochondrion & $2(1.8)$ & 0 & 2 & $\begin{array}{l}\text { Speech difficulty:1, } \\
\text { walking difficulty:1, } \\
\text { vision problem:1, } \\
\text { ataxia:1, Seizure:1, } \\
\text { DD:2 }\end{array}$ \\
\hline 32 & Leigh syndrome & LS & 185620 & SURF1 & $\begin{array}{l}\text { Mitochondrion } \\
\text { inner membrane }\end{array}$ & $3(2.6)$ & 0 & 3 & $\begin{array}{l}\text { Muscle weakness:3, } \\
\text { walking problem:3, } \\
\text { swallowing problem:2, } \\
\text { R:3, DD:1 }\end{array}$ \\
\hline 33 & $\begin{array}{l}\text { Mitochondrial complex I } \\
\text { deficiency, nuclear type } \\
5\end{array}$ & MC1DN5 & 618226 & NDUFS1 & $\begin{array}{l}\text { Mitochondrion } \\
\text { inner membrane }\end{array}$ & $1(0.9)$ & 0 & 1 & $\begin{array}{l}\text { Walking problem, } \\
\text { Seizure, MR }\end{array}$ \\
\hline 34 & $\begin{array}{l}\text { Mitochondrial complex I } \\
\text { deficiency, nuclear type } \\
3\end{array}$ & MC1DN3 & 618224 & NDUFS7 & Mitochondrion & $1(0.9)$ & 0 & 1 & Hypotonia, Seizure \\
\hline 35 & $\begin{array}{l}\text { succinate } \\
\text { dehydrogenase complex } \\
\text { assembly factor } 1 \\
\text { deficiency }\end{array}$ & MCIID & 252011 & SDHAF1 & Mitochondrion & $1(0.9)$ & 0 & 1 & $\begin{array}{l}\text { Speech problem, } \\
\text { walking problem, R }\end{array}$ \\
\hline Total & & & & & & $\begin{array}{l}114 \\
(75)\end{array}$ & $\begin{array}{l}74 \\
(49 \%)\end{array}$ & $\begin{array}{l}40 \\
(26 \%)\end{array}$ & \\
\hline
\end{tabular}

DD: Developmental delay; LD: learning difficulties; Cl: Cognitive impairment; MR/R: Motor regression/retardation; MD: motor delay, MD; AG: Abnormal gait; ER: Endoplasmic reticulum 
Table 2:

Novel variants identified in this study

\begin{tabular}{|c|c|c|c|c|c|c|c|c|c|}
\hline No. & Nucleotide change & AA change & Gene & $\begin{array}{l}\text { no. of } \\
\text { patients }\end{array}$ & Zygosity & ACMG & MutationTaster & $\begin{array}{l}\text { Polyphen- } \\
2\end{array}$ & CAD \\
\hline 1 & c. $2099 \mathrm{~A}>\mathrm{C}$ & p. Asn700Thr & POLR3B & 1 & Hom & $\begin{array}{l}\text { Likely } \\
\text { pathogenic } \\
\text { (2) }\end{array}$ & DC & PD 0.998 & 27.: \\
\hline 2 & c. $786 A>C$ & p. GIn262Asp & SLC17A5 & 1 & Hom & $\begin{array}{l}\text { Likely } \\
\text { pathogenic } \\
\text { (2) }\end{array}$ & DC & PD 1.000 & 24. : \\
\hline 3 & c. 904_905delinsAT & p. Glu302Met & $A B C D 1$ & 1 & Hemi & $\begin{array}{l}\text { Likely } \\
\text { pathogenic } \\
\text { (2) }\end{array}$ & DC & NA & 26.8 \\
\hline 4 & c. $1628 \mathrm{C}>\mathrm{G}$ & p. Pro543Arg & $A B C D 1$ & 1 & Hemi & $\begin{array}{l}\text { Likely } \\
\text { pathogenic } \\
\text { (2) }\end{array}$ & DC & PD 1.000 & 23.4 \\
\hline \multirow[t]{2}{*}{5} & c. $2002 \mathrm{~A}>\mathrm{G}+$ c. $1021 \mathrm{G}>\mathrm{T}$ & $\begin{array}{l}\text { p. Thr668Ala+p. } \\
\text { Ala341Ser }\end{array}$ & $A B C D 1$ & 1 & Hemi & $\begin{array}{l}\text { Likely } \\
\text { pathogenic } \\
\text { (2) }\end{array}$ & DC & PD 0.761 & 23. \\
\hline & & & & & & $\begin{array}{l}\text { Likely } \\
\text { pathogenic } \\
\text { (2) }\end{array}$ & & & \\
\hline 6 & c. $839 \mathrm{G}>\mathrm{C}$ & p. Arg280Pro & $A B C D 1$ & 1 & Hemi & $\begin{array}{l}\text { Likely } \\
\text { pathogenic } \\
\text { (2) }\end{array}$ & DC & PD 1.000 & 32 \\
\hline 7 & c. $233 \mathrm{C}>\mathrm{A}$ & p. Ser78Ter & RNASET2 & 1 & Hom & $\begin{array}{l}\text { Pathogenic } \\
\text { (1) }\end{array}$ & DC & NA & 36 \\
\hline 8 & $\begin{array}{l}\text { c. } \\
\text { 437_449delCTCTGGCTCCACT }\end{array}$ & $\begin{array}{l}\text { p. } \\
\text { Ser146TyrfsX7 }\end{array}$ & $A S P A$ & 1 & Hom & $\begin{array}{l}\text { Pathogenic } \\
\text { (1) }\end{array}$ & DC & NA & 34 \\
\hline 9 & c. $359 \mathrm{C}>\mathrm{T}$ & p. Ser120Phe & $A S P A$ & 1 & Hom & $\begin{array}{l}\text { Uncertain } \\
\text { significance } \\
\text { (3) }\end{array}$ & DC & PD 1.000 & 29. \\
\hline 10 & c. $866 \mathrm{G}>\mathrm{A}$ & p. ser289lle & EIF2B4 & 1 & Hom & $\begin{array}{l}\text { Uncertain } \\
\text { significance } \\
\text { (3) }\end{array}$ & DC & B 0.002 & 22. ${ }^{\prime}$ \\
\hline 11 & c. $422 \mathrm{G}>\mathrm{T}$ & p. Gly141Val & FUCA1 & 1 & Hom & $\begin{array}{l}\text { Likely } \\
\text { pathogenic } \\
\text { (2) }\end{array}$ & DC & PD 1.000 & 28.1 \\
\hline 12 & c. 82 delG & $\begin{array}{l}\text { p. } \\
\text { Val28CysfsX105 }\end{array}$ & FUCA1 & 1 & Hom & $\begin{array}{l}\text { Pathogenic } \\
\text { (1) }\end{array}$ & DC & NA & $\begin{array}{l}16 . \\
62\end{array}$ \\
\hline 13 & c. $830 \mathrm{G}>\mathrm{A}$ & p. Ser277Asn & $G A L C$ & 1 & Hom & $\begin{array}{l}\text { Likely } \\
\text { pathogenic } \\
\text { (2) }\end{array}$ & DC & PD 0.946 & 23. ${ }^{\prime}$ \\
\hline 14 & c. $1942 \mathrm{~A}>\mathrm{T}$ & p. Lys648Ter & $G A L C$ & 1 & Hom & $\begin{array}{l}\text { Uncertain } \\
\text { significance } \\
\text { (3) }\end{array}$ & DC & NA & 36 \\
\hline 15 & c. $408+1 G>C$ & - & $\angle 2 H G D H$ & 1 & Hom & $\begin{array}{l}\text { Pathogenic } \\
\text { (1) }\end{array}$ & DC & NA & 34 \\
\hline 16 & c. $1213 \mathrm{~A}>\mathrm{G}$ & p. Arg405Gly & $\angle 2 H G D H$ & 1 & Hom & $\begin{array}{l}\text { Uncertain } \\
\text { significance } \\
\text { (3) }\end{array}$ & DC & PD 1.000 & 22. \\
\hline 17 & c. $183 \mathrm{C}>\mathrm{A}$ & p. Cys61Ter & $M L C 1$ & 1 & Hom & $\begin{array}{l}\text { Pathogenic } \\
\text { (1) }\end{array}$ & DC & NA & 37 \\
\hline 18 & c. $819 \mathrm{C}>\mathrm{G}$ & p. Phe273Leu & $M L C 1$ & 1 & Hom & $\begin{array}{l}\text { Uncertain } \\
\text { significance } \\
\text { (3) }\end{array}$ & DC & PD 0. 990 & 24. \\
\hline 19 & c. $571 \_572$ insC & $\begin{array}{l}\text { p. } \\
\text { Thr195AspfsX69 }\end{array}$ & GJC2 & 1 & Hom & $\begin{array}{l}\text { Pathogenic } \\
\text { (1) }\end{array}$ & DC & NA & 17.! \\
\hline 20 & c. $118 \mathrm{G}>\mathrm{C}$ & p. Ala40Pro & GJC2 & 2 & Hom & $\begin{array}{l}\text { Likely } \\
\text { pathogenic } \\
\text { (2) }\end{array}$ & DC & PD 1. 000 & 24.1 \\
\hline 21 & c. $733 \mathrm{~T}>\mathrm{A}$ & p. Cys245Ser & GJC2 & 2 & Hom & $\begin{array}{l}\text { Likely } \\
\text { pathogenic } \\
\text { (2) }\end{array}$ & DC & PD 1.000 & 25. \\
\hline
\end{tabular}




\begin{tabular}{|c|c|c|c|c|c|c|c|c|c|}
\hline 22 & c. $883 \mathrm{C}>\mathrm{T}$ & p. GIn295Ter & GJC2 & 1 & Hom & $\begin{array}{l}\text { Likely } \\
\text { pathogenic } \\
\text { (2) }\end{array}$ & DC & NA & 38 \\
\hline 23 & c. 529_531delAAA & p. Lys177del & PEX13 & 1 & Hom & $\begin{array}{l}\text { Pathogenic } \\
\text { (1) }\end{array}$ & DC & NA & 22. : \\
\hline 24 & c. $345 \mathrm{C}>\mathrm{G}$ & p. Ile115Met & PEX14 & 1 & Het & $\begin{array}{l}\text { Uncertain } \\
\text { significance } \\
\text { (3) }\end{array}$ & DC & $\begin{array}{l}\text { PD } 0 . \\
999\end{array}$ & 23.! \\
\hline 25 & c. $655 \_657 d$ delATT & p. Ile219del & $H E X B$ & 1 & Hom & $\begin{array}{l}\text { Pathogenic } \\
\text { (1) }\end{array}$ & DC & NA & 20.: \\
\hline 26 & c. $754 \mathrm{C}>\mathrm{T}$ & p. Arg252Cys & HEXA & 1 & Hom & $\begin{array}{l}\text { Likely } \\
\text { pathogenic } \\
\text { (2) }\end{array}$ & DC & PD 1.000 & 30 \\
\hline 27 & c. $1147-1 \mathrm{G}>\mathrm{T}$ & - & HEXA & 1 & Hom & $\begin{array}{l}\text { Pathogenic } \\
\text { (1) }\end{array}$ & DC & NA & 28. : \\
\hline 28 & c. $16 \mathrm{C}>\mathrm{T}$ & p. Arg6Cys & PLA2G6 & 1 & Hom & $\begin{array}{l}\text { Uncertain } \\
\text { significance } \\
\text { (3) }\end{array}$ & DC & $\begin{array}{l}\text { PD } 0 . \\
994\end{array}$ & 25 \\
\hline 29 & c. $416 \mathrm{~T}>\mathrm{A}$ & p. Leu139GIn & GLB1 & 1 & Hom & $\begin{array}{l}\text { Likely } \\
\text { pathogenic } \\
\text { (2) }\end{array}$ & DC & PD 1.000 & 29.: \\
\hline 30 & c. $997 \mathrm{G}>\mathrm{T}$ & p. Asp333Tyr & SUCLA2 & 1 & Homo & $\begin{array}{l}\text { Likely } \\
\text { pathogenic } \\
\text { (2) }\end{array}$ & DC & PD 1.000 & 31 \\
\hline 31 & c. $3482+6 C>T$ & - & POLG & 1 & Hom & $\begin{array}{l}\text { Uncertain } \\
\text { significance } \\
\text { (3) }\end{array}$ & DC & NA & 9.6 \\
\hline 32 & c. $29 A>C$ & p. Gln10Pro & SDHAF1 & 1 & Hom & $\begin{array}{l}\text { Uncertain } \\
\text { significance } \\
\text { (3) }\end{array}$ & DC & PD 1.000 & 27 \\
\hline 33 & c. $808 \_812$ delGAGCA & $\begin{array}{l}\text { p. } \\
\text { Glu270SerfsX20 }\end{array}$ & SURF1 & 1 & Hom & $\begin{array}{l}\text { Pathogenic } \\
\text { (1) }\end{array}$ & DC & NA & 35 \\
\hline 34 & c. $362+5 G>A$ & - & PPT1 & 1 & Hom & $\begin{array}{l}\text { Pathogenic } \\
\text { (1) }\end{array}$ & DC & NA & $21 .{ }^{\prime}$ \\
\hline 35 & c. $659 \mathrm{~A}>\mathrm{C}$ & p. Tyr220Ser & CLN6 & 1 & hom & $\begin{array}{l}\text { Uncertain } \\
\text { significance } \\
\text { (3) }\end{array}$ & DC & PD 0.986 & 32 \\
\hline 36 & c. $392 \mathrm{C}>\mathrm{A}$ & p. Thr131Lys & HSD17B4 & 1 & Hom & $\begin{array}{l}\text { Likely } \\
\text { pathogenic } \\
\text { (2) }\end{array}$ & DC & PD 0.985 & 33 \\
\hline 37 & c. $1285 \mathrm{G}>\mathrm{A}$ & p. Val429Met & NDUFS1 & 1 & Hom & $\begin{array}{l}\text { Likely } \\
\text { pathogenic } \\
\text { (2) }\end{array}$ & DC & PD 0.971 & 28.1 \\
\hline 38 & c. $415 \mathrm{G}>\mathrm{A}$ & p. Asp139Asn & NDUFS7 & 1 & Hom & $\begin{array}{l}\text { Likely } \\
\text { pathogenic } \\
\text { (2) }\end{array}$ & DC & PD 1.000 & $25 . !$ \\
\hline
\end{tabular}

DC: disease causing, PD: probably damaging, Hom= homozygous, $\mathrm{B}=$ benign, $\mathrm{NA}=$ not available

\section{Figures}




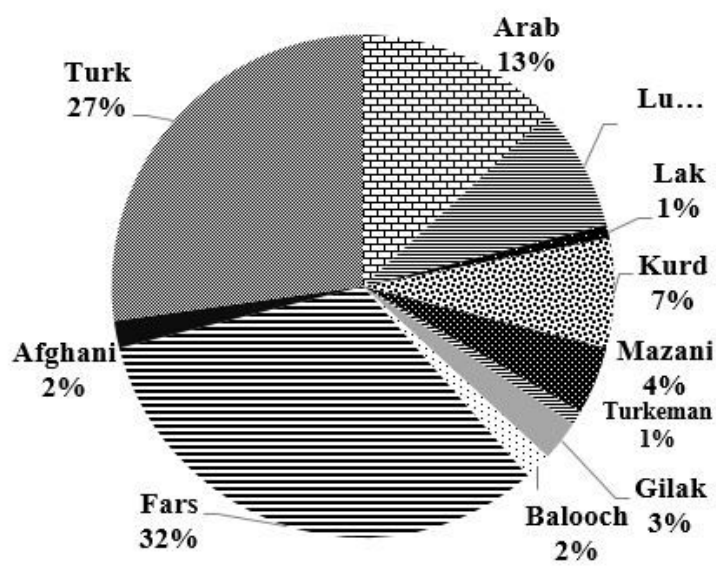

A

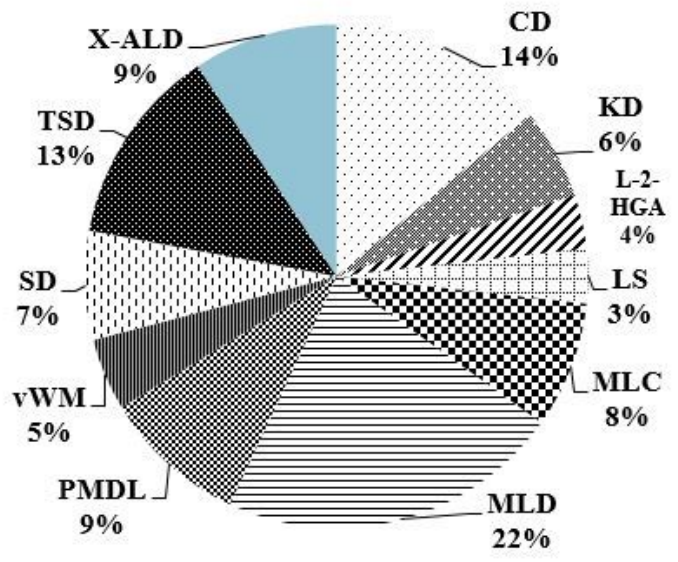

B

\section{Figure 1}

A) The distribution of 114 leukodystrophy genotype positive patients in Iran, based on ethnicity. B) The distribution of the most common diagnosed leukodystrophies (86 of 114 patients) in our studied patients include 19 of 86 (22\%) metachromatic leukodystrophy (MLD), 12 Canavan (CD), 11 Tays-Sachs disease (TD), 7 megalencephalic leukodystrophy with subcortical cysts (MLC), 8 X-linked adrenoleukodystrophy (X-ALD), 8 Pelizaeus-Merzbacher-like disease type 1 (PMLD), 6 Sandhoff disease (SD), 4 VWM (Leukoencephalopathy with vanishing white matter) and 3 L-2-HGA(L-2-hydroxyglutaric aciduria disease).

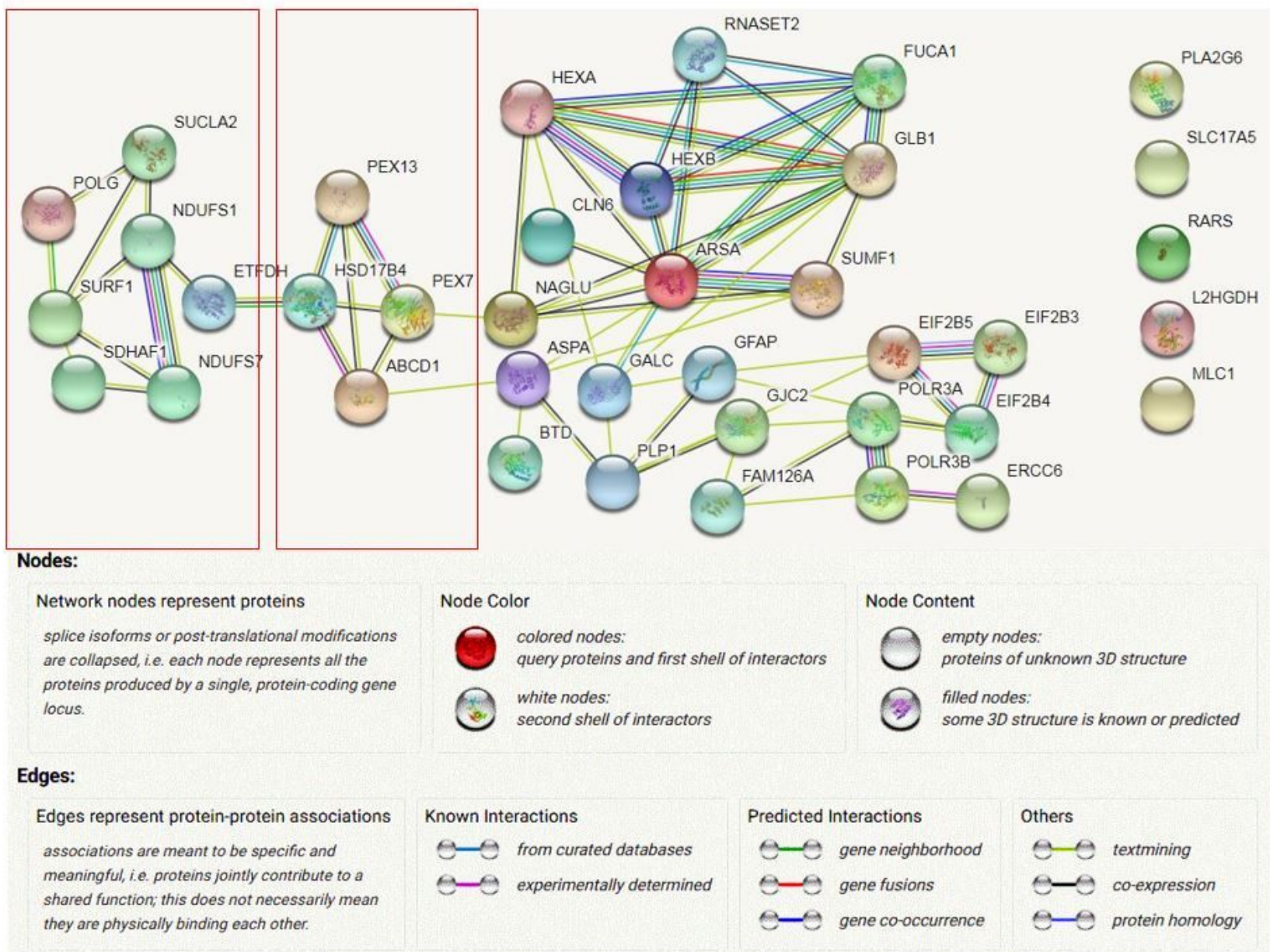


Protein interaction-interaction analysis. Mitochondrial (POLG, SUCLA2, NDUFS1, SURF1, ETFDH, SDHAF1, NDUFS7) and peroxisomal proteins (PEX13, HSD17B4, PEX7, ABCD1) are showed in rectangles. Other genes including the one in lysosomes are shown in middle panel. Some proteins show no interaction with other proteins (PLA2G6, MLC1, L2HGDH, RARS, SLC17A5). The Protein-protein interaction is categorized based on one of seven channels : 1-3) genomic context (neighborhood, fusion, gene co-occurrence), 4) co-expression, 5) text-mining, 6) biochemical/genetic data ('experiments') and 7) previously curated pathway and protein-complex knowledge ('databases').

\section{Supplementary Files}

This is a list of supplementary files associated with this preprint. Click to download.

- Supplemantarytableleuko.docx 